\title{
THE WORLD OF TRANSLATION
}

\author{
Susi Harliani \\ (Politeknik Elektronika Negeri Sirabaya/susih@pens.ac.id)
}

\begin{abstract}
Basically, transferring message from the source to target language is not just changing the language, as there is multidiscipline process in the translation. The complexity performed since the language is multi-system and its variety in communication is never apart from context. Therefore, the translation needs not only linguistics theory but also some other theories like socio-linguistics, psycholinguistics, pragmatics, contrastive analysis and cross culture understanding.
\end{abstract}

Keywords:

Source language; target language; transferring message

DOI: $10.19105 /$ ojbs.v13i1.2272

\section{A. Introduction}

According to Catford, "Translation is an operation performed on languages: a process of substituting a text in one language for another", ${ }^{1}$ while according to Nida and Taber, translating is an activity to reproduce messages in target language (TL) closely and naturally, commensurate with the one in the source language (SL), concerning its meaning and style. ${ }^{2}$ The two opinions above state that translation operates structure, meaning and style. In this case, linguistics, semantics, stylistics work together.

It is asserted by Wills that translating is not a simple task; in this case the ability to master several languages including linguistic aspects,

1 J. C. Catford, A Linguistik Theory of Translation (New York: Oxford University Press, 1974), 1.

2 A. Widyamartaya, Seni Menerjemahkan (Yogyakarta: Kanisius, 1989), 11. writing style and the ability to integrate those various masteries are needed, so that communicative translations can be produced in accordance with the level of readers understanding. ${ }^{3}$ It could happen that the better knowledge or mastery of linguistic structures and messages, someone will be more aware of his limitations in translating a message from one language into another. ${ }^{4}$

Meanwhile, language is a communication tool in which a piece of linguistic structure can represent various meanings, depending on the context, situation, participation, purpose and numerous cultural factors. Language cannot be separated from its contents and paralinguistic elements because it

3 Maurits Simatupang, Enam Makalah tentang Terjemahan (Jakarta: UKI Press, 1993), 77.

${ }^{4}$ E. Sadtono, Pedoman Penerjemahan (Jakarta: Pusat Pembinaan dan Pengembangan Bahasa, 1985), 26. 
has multi-functional. Language is the main substance of symbolic activity carried out by humans and it is a complex substance, ${ }^{5}$ and even a "... interrelated system of systems." ${ }^{\text {Based }}$ on those, text analysis does not rely solely on grammar, but it also needs to involve various reviews such as sociolinguistics, pragmatics and discourse analysis, psycholinguistics, contrastive analysis, and cross-cultural understanding.

\section{B. The Translation Essence}

The most common definition of translation, which is widely known, is the process of translating or copying from one language to another. In general, dictionaries have also stated that. This definition is obviously weak, because its substance only touches its surface extent. If it is just the translation of words per word, that definition may be acceptable.

Copying is not the same as translating. Copying means, "... menukar (exchanging), mengganti, (replacing) menurun (plagiarizing)". ${ }^{7}$ The sentence, "Ani menyalin buku itu ke dalam bahasa Inggris " cannot be interpreted simply as, "Ani translates the book". In this case maybe Ani has already changed the language in the original text, which had not been English into English, but it does

\footnotetext{
5 Mansoer Pateda, Sosiolinguistik (Bandung: Angkasa, 1991), 20.

6 W. F. Mackey, Language Teaching Analysis (London: Longman, 1965), 78.

7 W. J. S Poerwadarminta, Kamus Umum Bahasa Indonesia (Jakarta: Balai Pustaka, 1976), 856.
}

not mean that she has translated the text. Translating is not that simple.

According to Catford, translation is, "The replacement of textual material in one language (SL) by equivalent textual material in another language (TL)." Qualifications of total translation are defined as, "... replacement of SL grammar and Lexis by equivalent $\mathrm{TL}$ Grammar and Lexical with consequential replacement of TL phonology/ graphology by (nonequivalent) TL phonology/graphology." It can be seen that, beside the structure, the process of transferring messages also needs to be considered, as it is stated by Newmark, "Translation is a craft that is used to replace a written message and/ or statement, in a same message and/ or statement in another language". ${ }^{10}$ Furthermore, translation needs to be concerned with message qualifications; the more important the message part in $\mathrm{SL}$, the more attention should be given to translating, and vice versa; there should be a fidelity to the message.

There are times when fidelity is leaning on the structure of SL. When this happens, the message delivery is not optimal because the translator is overly attached to the form of word, phrase, and structure in the SL. As a result, the translation is unattractive and less communicative because the translator underestimates the TL text. Nida also

\footnotetext{
8 Catford, A Linguistik Theory of Translation, 1974, 20.

${ }^{9}$ Catford, 20.

10 Peter Newmark, Approaches to Translation (Oxford: Pergamon Press, 1981), 7.
} 
encourages translators to be true to their faithfulness, but this does not mean that they must be loyal to the SL. In this case what it meant by faithful is certainly faithful to the author's message. Larson, who described the translation process as follows, also emphasized the meaning of the message:

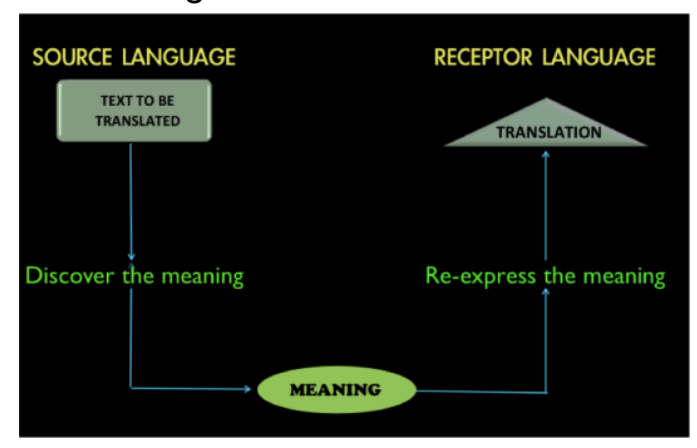

Picture 1. Translation Process ${ }^{11}$

Larson stated, "... translation consist of transferring the meaning of source language into the receptor language. This is done from the form of the first language to form of second language by the way of semantic structure."12 Based on his statement, it can be seen that the term of meaning or semantics organization is prioritized. So, the essence of translation is transferring the meaning. In relation with this, Bell stated, "Translation is an expression in another language (or target language) of what has been expressed in another, source language, preserving semantic and stylistic equivalences."13 Obviously, in order that communicative translations can be produced in accordance with the

11 Mildred L. Larson, Meaning Based Translation (Maryland: University Press of America, 1984), 4.

12 Larson, 3.

13 Roger T. Bell, Translation and Translating: Theory and Practice (London: Longman, 1997), 5. level of ability of the reader, an interpreter cannot ignore the stylistic aspect. Nida's definition seems to be more complete. It is stated as follows: ${ }^{14}$

"That is to say, the translator first analyzes the message of the source language into its simplest and structurally clearest form, transfers it at this level, and then restructures it to the level in the receptor language which is most appropriate for the audience which he intends to reach".

According to Nida, first of all a translator must be able to analyze the message written in SL as clearly as possible, after that he must transfer it into $\mathrm{TL}$ completely by maintaining its equivalence, then rearrange the message in $T L$ in such a way that it is well understood in the level of the reader understanding. Nida apparently not only emphasized that the translator must know the author's message, but also he emphasized that the translator must know how to convey the message in the translation. Noticeably, fidelity to $T L$ is also important. According to Hardjo prawiro, however, translators must, "... be more faithful to the target language."15

A translator, who has been able to understand well the message of the author, is not necessarily able to produce quality translations and is easy to read. To produce quality translations, translators must master TL. Mistakes in

14 Eugena A. Nida, Language Structure and Translation (Stanford: Stanford University Press, 1975), 79-80.

15 Kunardi Hardjoprawiro, Bahasa Indonesia Dalam Terjemahan (Surakarta: Universitas Sebelas Maret, 1998), 4. 
re-expressing the author's message for the weak mastery of TL will waste all the hard-earned in understanding the message that has been done before. Then, to produce a readable translation, the translator must know well the level of readers understanding. Ignoring this matter will produce the boring and uninteresting translations.

Savory added that translations must be easy to read and enjoyable. ${ }^{16}$ This is related with Duff's opinion, which states that in any field if a text to be translated, the various levels of the reader's ability to understand the translated text cannot be ignored. So, it is very necessary for a translator to pay attention, "... for whom a translation is prepared and how readers' special ability level is". ${ }^{17}$

In translation activities, what actually happens is communication between the writer and the reader through the translator. The author acts as the sender of the message, it is captured first by the translator, after that be transferred from source to target language, for later be sent back to the reader. ${ }^{18}$ What must be maintained is how the message that goes through the communication chain reaches the reader completely. In this case the role of the translator is very important.

16 Theodore Savory, The Art of Translation (London: Jonathan Cape Thirty Bedford Square, 1969), 52.

17 Rudolf M. Nababan, Teori Menerjemah Bahasa Inggris (Yogyakarta: Pustaka Pelajar, 1999), 2021.

18 H. W. Hollander, Penerjemahan Suatu Pengantar (Jakarta: Erasmus Tallcentrum, 1995).
In carrying out the duties, it is not enough for the translator to merely use dictionary as there are various word meanings written in it and by all means there is only one proper meaning to express the source language text message. As a matter of fact, it is not enough for the translator to master simply two languages involved. Translating is not merely dealing with words, phrases, sentences or forms of discourse, as Frawley affirms, “.... Translating is more than a triple matching of words, grammatical structures, and cultural contexts which in itself would already be a formidably complex process." 19

In his role as a messenger or liaison between the writer and the reader, the translator plays a dual role: as the recipient and the message giver. As the recipient of message, he needs to involve himself in SL natural communication; at the same time, he also acts as the giver/ messenger of $\mathrm{TL}$ and for undertaking that he is demanded to act fairly. Excessive tendency to one side - SLor TL-- will tend to underestimates for the other side. This matter will clearly distort the message to be conveyed. So, the translator must be able to undertake as "... objective mediator" for both sides. ${ }^{20}$ Moreover, basically a translator must also have a

\footnotetext{
19 William Frawley, Translation, Literary, Linguistic, and Philosophical Perspective (London: Associated University Press, 1984), 43.

20 Richard W. Brislin, Translation Application and Research (New York: Gardner Press Inc, 1976), 289.
} 
moral responsibility to convey the truth, as stated by Newmark, "Translation is concerned with moral and with factual truth. This truth can be effectively rendered only if it is grasped by the reader, and that is the purpose and the end of translation." 21

\section{Various Disciplines Involved in Translation}

\section{Translation Theory}

Although people before have done translation, since the time of Hammurabi in Babylon, ${ }^{22}$ it does not mean that translation theory is not needed. The translation theory is available and needed to guide the translator's steps to do his work. With the translation theory, a translator will have basic knowledge and knowledge of the translation process, which allows him to work more systematically, methodologically and effectively. ${ }^{23}$ It is impossible for a translator to produce a good translation if he for example, does not understand the definition and essence of translation as one of the concepts of translation theory. With the theory of translation, a translator will get a clear picture of translating, especially nowadays where the theory of translation has begun to develop. The main task of translation theory is to discuss and analyze what is called, "... functional equivalents" and

21 Peter Newmark, About Translation (Clevedon: Multilingual Matters Ltd, 1991), 1.

22 Eugena A. Nida, Toward A Science of Translating (Leiden: E. J. Brill, 1964), 11.

23 Bell, Translation and Translating: Theory and Practice, 22. various conditions that must be met to realize the equivalence of messages between the two languages. ${ }^{24}$ It is not rare for translators having difficulty in seeking and finding a suitable equivalent. For this reason, translation theory can recommend a method to choose from.

The fact is that literal translation techniques which is applied to meet the needs of translation works produce the no optimal translations for there are quite a lot of message elements in SL that are not revealed in the $T L$ Translation theory mastered by a translator will be able to minimize those message elements in SL that are not revealed. The phrases like 'si jago merah sedang mengamuk'. 'kabar angin itu sempat meresahkan hatinya', 'ia mengambil langkah seribu karena takut' would be odd when 'si jago merah sedang mengamuk', is translated as, 'red rooster is being angry', 'kabar angin itu sempat meresahkan hatinya' is translated as 'This news of the wind troubles his heart' and 'la mengambil langkah seribu karena takut'. are translated as 'He takes a thousand steps because he's scare.'

Those examples show that the translator simply adjusts 'jago merah' with red rooster', 'kabar angin' with 'news of the wind' and 'langkah seribu' with 'a thousand steps'. In this case, the translator does not understand the idiomatic processes that occur in the

24 Maurits Simatupang, Enam Makalah Tentang Terjemahan (Jakarta: UKI Press, 1993), 26. 
construction. He did not realize that in SL the formation of 'jago merah', 'kabar angin' and 'langkah seribu' are acceptable and have semantic background, while 'red rooster', 'news of the wind' and a thusand step' in TL are not acceptable. He failed in the phase, which Bell called a semantic representation phase. ${ }^{25}$ Perhaps he does not understand that in translation there is such a process. Catford affirmed, "The central problem of translation practice is that the finding $T L$ translation equivalents. A central task of translation theory is that of defining the nature and conditions of translation equivalence." ${ }^{26}$ So, the main problem in translation is how to find out equivalence in SL, and to resolve it, the theory is able to play a role, maintain the naturalness and reasonableness the translation, so that the translation will appears and sorely an original work.

In translation theory, there are various approaches, depending on the function and type of SL text, which is faced by the translator. The approach applied to translate the literature works (which tends to be expressive), for example, it is certainly different from the one that is used to translate scientific work (which tends to be informative and argumentative), as stated by Duff, "In scientific and academic translation, extreme precision is often required. By

25 Bell, Translation and Translating: Theory and Practice, 21.

${ }^{26}$ J. C. Catford, A Linguistik Theory of Translation (New York: Oxford University Press, 1974), 21. retaining the source language expression, the translator can indicate to the reader where the 'danger spot' lie". ${ }^{27}$ In this case, high precision as meant by Duff is certainly needed because what the translator faces is a scientific and not literary work. It is not impossible to occur when this matter escape from ordinary translator's observations, who does not understand the translation theory.

In essence, theory is an explanation or series of explanations concerning a system, which can be realized into a particular model. By mastering translation theory, a translator will understand well the meaning of translation, its type and function, how to translate, the difference between translating scientific and literature work, the uniqueness of the language and the translation process. Without mastering the translation theory, a translator will only comprehend that translating is nothing more than transferring the language.

\section{Linguistic Theory}

General linguistic theory, which is able to define language correctly, contains a description of the language nature, is important for the translation. A translator who does not understand the nature of language, will certainly face many obstacles in the implementation of his duties. By understanding the nature of language, a translator will be more carefully in doing his work. In the

27 Allan Duff, The Third Language (Oxford: Pergamon Press, 1981), 11. 
translation process, grammar plays very important role in reconstructing and reexpressing $\mathrm{SL}$ into the BSa text. By mastering the structure, the translator will be able to do a grammatical analysis of $\mathrm{SL}$ texts. He will be able to distinguish words from phrases, phrases from clauses and clauses from sentences. "Nida and Taber show the importance of grammatical analysis, because grammar has meaning and determines meaning", stated Suryawinata ${ }^{28}$ and in relation to that Halliday asserts, "Language... gives structure to experience, and helps to determine our way of looking at things, so that it requires some intellectual effort to see them in any other way than that which our language suggest to us." ${ }^{29}$ The following translation can be stated as the examples:

ENG: The First Third Country Training purposes to give a foothold in life for the participant.

IND: Tujuan Penataran Pertama untuk Negara Dunia Ketiga ialah memberi kedudukan untuk kehidupan peserta.

The example above shows that the translator fails to translate English sentences correctly because he fails to identify the group of words The First Third Country Training purposes. As a result, he fails to explore and formulate the grammatical meaning of SL's text. In

28 Zuchridin Suryawinata, 'Analisis dan Evaluasi terhadap Terjemahan Novel Sastra the Adventures of Huckleberry Finn dari Bahasa Inggris Ke Bahasa Indonesia' (Dissertation, FPS IKIP Malang, 1982), 51.

${ }^{29}$ Mona Baker, In Other Words, A Course Book on Translation (London: Routledge, 1992), 82. this case, the translator apparently is misled by the word 'purposes', so he considered it as a head phrase, and the word 'ialah' appears. When the English sentence is observed, especially the group 'The First Third Country words Training purposes', it can be recognized that its head phrase is the word 'Training'. Words group 'The First Third Country' acts as a modifier. So, the translation, which is certainly more acceptable is: Pelatihan Pertama untuk Negara Dunia Ketiga bertujuan memberikan bekal hidup kepada peserta. If this translation is noted, it can be seen that 'foothold in life' is translated as 'bekal hidup'. This equivalence is done on the basis of the idiomatic meaning that arises. Furthermore, if the translation is observed it will also be seen that there are differences in the grammatical system between SL and ST. For example, the 'Third Country' has MD patterned is translated as 'Negara Ketiga' which has DM.

By mastering grammar, a translator will also be able to overcome the problem of ambiguity; for example, in an English sentence, "There will be a match between you and me", it will not be translated as, 'Akan ada pertandingan antara kau dan aku', but, 'Akan ada keserasian antara kau dan $a k u$ '. That happens because the word 'match' can mean 'pertandingan' (competition), it can also be 'kesesuain' means suitability/ harmony. ${ }^{30}$

30 Nababan, Teori Menerjemah Bahasa Inggris, 67. 
In translation, sometimes difficulties arise related to extracting this grammatical meaning because of the great difference between BSu's linguistic system and the BSa linguistic system. In BSu text there are sometimes long or very long phrases, clauses or sentences, the elements of which may be difficult to identify. Given that meaning is an important aspect of translation, the problem of intimacy needs serious attention.

The first thing to do if someone translates is to read the SL text. Here a challenge must be faced, specifically the grammar of SL. The reliable tool here is mastery of SL grammar. Hollander clearly states the following: "What is important for the translator when reading the text is knowing the purpose and function of the language used by the author. The translator will in principle prioritize translation in the same language function as the original text. Only in this way can the translator be able to translate according to the author's intentions." ${ }^{31}$

The viewpoints above show how important the role of linguistic theory is to support translation. A study result states that in translating from English into Indonesian, translators can deal with serious problems in the form of long noun phrases which function ate as subjects. Such phrases can be confusing and even misinterpreted by

${ }^{31}$ Hollander, Penerjemahan Suatu Pengantar, 27. the translator so that the sentence is not recognized anymore. ${ }^{32}$

$$
\text { According to Soemarno, }
$$

"Translation error on English noun phrase shows a high frequency compared to others." ${ }^{33}$ The lacks of understanding of the structure of SL lead the translator to do word-for-word translation, which obviously make the translation unattractive. "If the structure analysis is carried out properly, the translator will know which parts should be translated first."34

In translating, it is common to find $\mathrm{SL}$ texts with long sentences, in which when the translator is less critical, it will be difficult to find the basic elements. The number of auxiliary elements in the form of additional information and description of the composition can be the cause of this, particularly when the SI text itself does not use punctuation correctly and clearly (for example, no quotation marks to express direct excerpts) so that the reader must strive to observe and determine what is read is direct or indirect sentence. ${ }^{35}$

Furthermore, in the semantic field, the translator will deal with the problem of idiomatic, sociocultural, implicit,

\footnotetext{
32 Thomas Soemarno, 'Studi Tentang Kesalahan Terjemahan Bahasa Inggris ke Dalam Bahasa Indonesia oleh Mahasiswa Yang Berbahasa lbu Bahasa Jawa' (Magister Thesis, IKIP Malang, 1983), 71.

33 Soemarno, 82.

34 Nababan, Teori Menerjemah Bahasa Inggris, 27.

35 Kunardi Hardjoprawiro, Menerjemahkan Novel (Jakarta: Pusat Pembinaan dan Pengembangan Bahasa, 1978), 7-9.
} 
textual and the speaker meaning. If the translator ignores all of those - as he does not understand it - he certainly cannot produce a good translation. 'ia gugur sebagai bunga bangsa'; 'ia membanting tulang', 'memeras keringa't; l'a tak mau menjadi katak dalam tempurung'; 'di atas langit masih ada langit'. To translate those sentences into English, it may be necessary to analyze semantic components, which are quite complicated. Another example, the words 'house' in English cannot simply be translated as 'omah', 'griya', or 'dalem' in Javanese, because the Javanese language distinguish the level of speech. Linguistic difficulties will emerge as the first problem that must be faced by a translator, after those problems like "... lexis and language will develop." 36

\section{Sociolinguistics}

As one of the culture elements, language blends with its users in society, and every member of the society that use such language will provide certain associations to everything depending on the circumstances or social cultural background of the concerned society. This can be seen from how the society inteprets anything that available and happens. Based on the above matter, what needs to be considered in translation is the fact that the SL text

36 Soemarno, 'Studi Tentang Kesalahan Terjemahan Bahasa Inggris ke Dalam Bahasa Indonesia Oleh Mahasiswa Yang Berbahasa lbu Bahasa Jawa', 5. writer is also a member of the languageuser society, which cannot be separated from all forms of subjectivity in intepreting anything. When a writer for instance, uses elements of dialect, pidgin or creole in his writing, that is the reality that should be handled objectively. In such cases, inter alia, translation requires a sociolinguistic contribution.

Different level of society leads to differences language use, so that a variety of language use is created. Various kinds of language usage arise due to geographical background, the social status of the society, the subject matter, the society profession, and nature of the situation. The scientific range is indeed different from the range of literatures, social diversities are different from techniques varieties, the variety of doctors is different from the traders, and the official range differ from the casual one. In relation to multi-level language-use in societies, any different of sociocultural conditions and levels of education, comprehension of contextual meaning in language might also be varied.

Hence, connotation meaning of a word or phrase can be different one society to another. To answer this, a sociolinguistic study is needed. The expressions such as 'dilemarieskan', 'anak bangsa', 'rakyat', 'jihat', 'membebek', kambing hitam', 'dagang sapi', 'gunung es', 'kawah candradimuka', obviously cannot be translated literally, and sociolinguistic 
background must be considered. The meaning of 'lemari es', related to its context and can only be understood by educated people. Less educated people can be confused in understanding the meaning of 'dilemarieskan' Likewise 'anak bangsa', 'rakyat' and others. Someone who will translate those phrases into English, requires to explore the emergence motivation of those term, which may have never been acknowledged in English speaking country. By understanding this matter and considering the readers' ability, translator will respond to the emergence of this problem wisely. The sociolinguistic study will be able to prevent the translation of the SL text in one range into the TL text in a different one.

Another example, a Javanese word 'panjenengan' cannot simply be translated with 'anda' in Indonesian, or 'you' in English. On the contrary, the English word 'yes' is not necessarily equivalent to being translated into ' $y a$ ' in Indonesian, or 'inggih' in the Javanese. What about the trend of certain language to use more passive sentences? Indonesian with Sundanese dialect for example, can be an example here. In that dialect, the sentence, buku itu ada di mana?' ('Where is the book?') Is more often said 'Buku itu ditaruhnya di mana?' ('Where is the book put it?') To answer the questions like this, the translation requires sociolinguistic support.

\section{Psycholinguistics}

In written

translation, Psycholinguistics seems to show its less contribution. However, in spoken translation, the role of Psycholinguistics is really numerous. As it is discussed earlier, an important process in translation is reproducing messages. In this case the role of Psycholinguistics in translation seems to be clear. In the process of reproducing messages, there are two dominant roles, namely mastery of $\mathrm{TL}$ and understanding of message recipient existence. These two things are closely related. Even though the translator has good linguistic capabilities in the $T L$, he still needs to have communicative competence by considering sociolinguistic factors that cannot be ignored. This means that in the process of reproducing the message, he needs to pay attention to who the message recipient is, where he is, when, in what situation, and so on. Therefore, knowing who the source and message recipient is, what nationality and the cultural background he has, and what they want to get from those interaction, are very important. ${ }^{37}$

According to Altman as cited by Thomas \& Towell, a translator needs to have four skills: (1) master the source language (SL); (2) master the target language ( $T L)$; (3) sensitive toward the content of speech; (4) competent in

\footnotetext{
${ }^{37}$ Noel Thomas and Richard Towell, Interpreting as a Language Teaching Technique (United Kingdom: University of Salford, 1985), 15.
} 
facing the public. ${ }^{38}$ When it is observed carefully, Altman's formula implies that there is a complex mentality process of a translator when he reproduces a message. When he reproduces a message, it is very likely that at the same time, cognitive processes take place within him as in simultaneous interpretation: when the source message speaks, the translator is also speaking. That is the translators demand on one hand. On the other hand, then he also needs to constantly keep the sentences hold the pattern which is spoken by source message; long sentences need to be prevented as they are impossible; he can't perceive in advance; his translation will tend to be a word for word, but by all mean everything he says should be meaningful, and the word for word translation is not possible to carry out.

Once the source news starts speaking, the translator must also be ready to start speaking; once the translator starts the sentence, he is like jumping in the dark; the grammatical form of the sentence cannot be immediately determined and ending the sentence is not as easy as starting it. In such circumstances, agility is needed to guide his mind to go through complicated syntactic system. 'Listening intently to translating half-unconsciously, consciously interviewing redness the former and balanced of syntax, touching

38 Thomas and Towell, 13-16. up, putting the fillers', this is what Gerver concluded. ${ }^{39}$

In describing the existence of this mentality process, Hromosovae reported an interaction between short-term memory and long-term memory which is called the term three-track memory, in the form of the following situations: ${ }^{40}$ (1) once the conversation in the $\mathrm{SL}$ is started, the interpreter starts saving; (2) once the interpreter saves, he also brings all his knowledge of vocabulary and grammar of SL and TL into his short-term memory; (3) as long as the results of the translation are spoken, the above cycle continues / repeats.

It is noticeably how complicated the mentality process that occurs in the translator himself when he translates verbally. The flow of activity in the process is so dense that high concentration is always needed to carry out this process. It is very important for the translators to have high concentration. The slightest interruption and disruption can damage the concentration and eventually damage the process that has already taken place, as it has ben demonstrated by Kade and Cartillieri in his research. ${ }^{41}$ They got the data there; it shows that the disturbances in the process of speech perception would force the interpreter/translator to repeat the process from the beginning. With the

\footnotetext{
39 Brislin, Translation Application and Research, 168.

40 Brislin, 191.

41 Brislin, 194.
} 
basis of the research results, they formulated, "The interpreter as listener makes probabilities inferences about the future development of a sentence on the basic of what he has just heard; his own utterances are then based on these predictions, becoming more determined as the source language sentence proceeds." 42

In the psycholinguistic study it is proven that the element of 'noise', which can occur in sound substitution, can reduce or interfere speech understanding. With the existence of 'noise', in terms of linguistics, the phonemic characteristic that is able to distinguish one speech element to another disappeared. Finally, there is obscurity. A phoneme can then exchange with other speech elements so that it is misunderstood. Speech elements, which should not available, could have appeared, and the result is the failure of communication. ${ }^{43}$

It can be seen from the formula that in the mentality process the translator has assumption or expectations that give him the opportunity to make inference possibilities about the sentence he later imagines on the basis of what he hears. Furthermore, the sentence he produces will be based on that prediction. This is in accordance with the results of

42 Brislin, 194.

43 Robert Lado, Language Teaching (New York: Mc. Grow Hill, 1964), 72. psycholinguistic studies. ${ }^{44}$ Therefore, if the translator/interpreter understands psycholinguistics, he will be able to respond to the reproductive process of his speech wisely.

As it is well known, Psycholinguistics considers language not just as a sign, but also as a psychological phenomenon; and psycholinguistics approaches language with concrete appreciation in psychological systems, understands how to produce and understand the language signs up to the cognitive abstraction systems, including memory of construction and interpretation of messages. ${ }^{45}$ The assessment of psychological processes about language proficiency and its implementation is called Psycholinguistics. ${ }^{46}$

The interesting psycholinguistic findings to look at in relation with mentality processes in oral translation are the existence of conclusions which states that in the process of understanding speech, a person is involved with assumptions that are born from the existence of speculations in his mind. ${ }^{47}$ Chernov reported that $75 \%$ of the research subjects responded to

\footnotetext{
44 Jean Aitchison, The Articulate Mammal: An Introduction to Psycholinguistics (London: Routledge, 1993), 203-40.

45 Michael Garman, Psycholinguistics (Cambridge: Cambridge University Press, 1994), $\mathrm{xV}$.

46 Jean Caron, An Introduction to Psycholinguistics (New York: Harvester Weatsheat, 1992), 1.

47 Aitchison, The Articulate Mammal: An Introduction to Psycholinguistics, 204-15.
} 
inputs according to their expectations or assumptions, compared to relying solely on what they heard. ${ }^{48}$

Furthermore, in producing messages, translators need to look at the deep structure of SL utterances. Gerver stressed, "It is only a knowledge of deep structure that would enable an interpreter to translate this sentence". ${ }^{49}$ Based on that concept, when the translator faces a source of messages in long-windedly talk "... as it is often done by Japanese," 50 the problem obviously arises. In this case, the translator should be very clever to capture deep structure of long-winded sentence. Nida also states that the translator first wants to 'decode' the messages in SL into abstract forms before restructuring them into TL. ${ }^{51}$

It is not impossible that there will be a conflict between the translator and the recipient because what he gets is not in accordance with his expectations and assumptions. According to Anderson, as 'the man in the middle', the translator should have prepared for this situation, because he is the subject of the recipient's expectations. It is not even excessive to say that the translator actually has a role as a person who has power, because he monopolizes the

48 Brislin, Translation Application and Research, 195.

49 Brislin, 197.

50 Nababan, Teori Menerjemah Bahasa Inggris, 118.

51 Brislin, Translation Application and Research, 198. communication meaning between his two clients.

Because the translator works with high cognitive speed, it is not impossible for him to be unaware to make speech production errors, such as the occurrence of word transpositions, syllables or sounds, like wise undergo mispronunciation. ${ }^{52}$

\section{Pragmatic Discourse Analysis}

The first step in translating is to analyze SL text. So, the role of discourse analysis pragmatic is important in supporting translation. Chomsky once stated that, "... there are linguistic rules in mind which are actually difficult to interpret." ${ }^{\text {33 }}$ Although language is a tool for communicating and expressing ideas, heart's content and feelings, language is not something that is mastered by mind. ${ }^{54}$ Thus, language cannot be treated at will; it has its own rules. The mind of language user must adjust to these rules.

In fact, a person does not merely communicate with the linguistic structure media. He also communicates with his heart, thoughts and feelings, which are expressed by various attitudes, expressions, movements, so that it is driven by a presupposition and implicature. Grice gives an example: A: I am out of petrol; $B$ : There is a garage

\footnotetext{
52 Aitchison, The Articulate Mammal: An Introduction to Psycholinguistics, 243-57.

53 Nababan, Teori Menerjemah Bahasa Inggris, 166.

54 Hamid Hasan Lubis, Analisis Wacana Pragmatik (Bandung: Angkasa, 1994).
} 
round the corner. ${ }^{55}$ In the dialogue, B gives such answer because he cannot grasp the implicature that $A$ needed fuel for his car. Because translation is essentially a process of communication, obviously the elements of communication can make mistakes such as misstatement or misunderstanding. As someone in a spoken communication, who does not only use language but also movement, expression, attitude, tone, and pitch; in written communication it is expected that the same thing can happen, in the form of a psychological depiction. In this case the role of discourse analysis for translation has noticeable.

There are many nonlinguistic factors that play a role in forming a discourse and a discourse analysis should consider them. Factors of conditions, situations, talks, point of views, topics of discussion, etc. need to be analyzed first so that the conclusions that are drawn from the discussion are not external conclusions, but inner ones. In translation activities, what the translators face and will present is a discourse. So the discourse is actually the 'workspace' of the translator. Like in a workspace, translators should be very familiar with its characters, or even master its contents and details. Text, as a genre realization (verbal social

${ }^{55}$ H. Paul Grice, 'Logic and Conversation', in P. Cole and J. Morgan, Syntax and Semantics, Vol. 3 (New York: Academic Press, 1975). process), is "... a language that is carrying out a task." ${ }^{n 6}$

\section{Contrastive Analysis}

Bell stated, "Translation is the replacement of a representation of a text in one language by a representation of an equivalent text in a second language." ${ }^{57}$ Based on that, translation requires contrastive analysis, so that an equivalent translation can be produced. Although in the beginning this discipline was born to overcome the problem of language teaching, its role in translation was quite large because in the translation there was a process of comparing two texts, which not only included the meaning of the message, but also structure and even style. In the field of applied linguistics, contrastive analysis has been recognized as a supporter of translation activities, as Crystal stated, "The phrase contrastive analysis also identifies a general approach to the investigation of language, particularly as carried on in certain areas of applied linguistics, such as foreign language teaching and translation." 58

Translation always involves two languages, and each language has its own structure, even its own

\footnotetext{
${ }^{56}$ Halliday and Ruqaiya Hasan, Bahasa, Konteks, Dan Teks; Aspek-Aspek Bahasa Dalam Pandangan Semiotik Sosial (Yogyakarta: Gadjah Mada University Press, 1994), 13.

57 Bell, Translation and Translating: Theory and Practice, 6.

${ }^{58}$ David Crystal, A Dictionary of Linguistics and Phonetics (United Kingdom: Basil Blackwell Ltd, 1985), 74.
} 
uniqueness. ${ }^{59}$ The system that applies, and all the sociocultural nuances that occurs in language of $A(S L)$ are not always the same or similar to those in language of $B(T L)$; whereas the language itself is a form of expression of heart's content which is difficult to measure, as explained by Twadell:

"Some linguists say that languages differ unpredictably and without limit. Other linguists say that all languages are very much alike in their 'deep structure' and differ only in their 'surface structures', so far as FL learning is concerned, when deep structure is so deep that all languages are essentially alike, depth equals triviality, for practical pedagogical purposes." 60

In his struggle with the two languages involved, it is not impossible for the translator to meet parts of the source language text, which cannot be translated. This is certainly a problem for translators alone. The untranslatable linguistic and perhaps the untranslatable culture will be difficult to avoid. To address this problem, translation will require the contribution of contrastive analysis. In an effort to find the equivalent, which is suitable for a construction in source language, the translator can certainly do an analysis of the components of meaning so that the same elements and different ones between the two constructions will be seen.

59 Nida, Toward A Science of Translating, 3.

60 Farid M. Baradja, 'A Contrastive Analysis of Selected Patterns of the Noun Phrases and Verb Phrases of English and Indonesian' (Dissertation, University of California, 1971), 11.
A translator will also face the problem of comparing the structure. Although he will not do word-for-word translation, attention to the compatibility of the structure must be maintained. Although comparing deep structures is quite difficult to do, comparing surface structure of the two texts needs to be done, as it is mentioned by Pietro, "Contrasting such surface phenomenon as pronouns, gender systems and prepositional phrases is meaningless unless their relationship to underlying grammatical primes are mode explicit." 61 Therefore, it is actually not excessive if a translator is required to master the linguistic knowledge of both languages so that he can distinguish implicit and explicit grammatical relationships.

Furthermore, in a bilingual or especially multilingual society, interference is difficult to avoid. In translation, contrastive analysis can address the existence of interference in source language, because with contrastive analysis, interference will appear as the difference that can be identified by the translator. The sentences, "Semprotan air itu membuat para pengunjuk rasa kocar-kacir", "Masuknya keluar mana?" "Itu hargae berapa?" When it is translated into English for example, the translator must address the forms of interference in it. Another example: 'Baju anak itu kebesaran ketika dikenakannya'; 'Baju kebesaran raja tersimpan di sana' In responding to the two sentences for

61 Baradja, 11. 
example, the translator needs to distinguish the first 'kebesaran' (greatness), which contains an element of interference, states the nature (adjective), with the second 'kebesaran' which is free from interference, declares information (adverbs).

\section{The Cross Cultural Understanding (CCU)}

If someone is faced with a culture that has never been known or recognized, he will tend to make an assessment or address that culture with the basics or measures, which he has in his own culture. ${ }^{62}$ That can be understood because in human's lives there is a system of cultural values, in the cultural value system there are norms and those influence the mindset and this mindset underlies the pattern of action. How a person interprets a metaphorical expression, for example, will be greatly influenced by the values that have been imbued as part of his culture.

In essence, translation is a crosscultural activity because it involves at least two languages along with all cultural values they contain. A good translator is not only a bilingual, but should also be bicultural. With that consideration, the CCU is a discipline that is also needed to support translation. Tomasouw explained the meaning of CCU as follows:

62 Koentjaraningrat, Pokok-Pokok Antropologi Budaya (Jakarta: Gramedia, 1984), 57.
"We may say that by cross cultural understanding we mean understanding the culture of the target people so we can reconstruct our attitudes and world view: consequently, we become more tolerable and more generous toward strange ways that may be shown by the target language people." 63

According to Mohanty, translation is not only a bilingual activity, but also bicultural. ${ }^{64}$ That can be understood because there is a close relationship between language and culture. Language is an element as well as a media for revealing culture. According to Sapir and Whorf, the language they use can influence the way a nation views their world. Meanwhile Newmark states, "Generally, if there is a high degree of cultural equivalence, there is a case for a literal translation."65

Shaw in Soemarno states that language, using various symbols or emblems is useful as a means of expressing meaning derived from "... a culture that applies when someone writes."66 "Language is a guide to 'social reality', 'pattern behavior'", said Sapir. ${ }^{67}$ By realizing the close relationship

\footnotetext{
63 Pauline Tomasouw, Buku Materi Pokok CrossCulture Understanding (Jakarta: Karunia, 1986), 1.17 .

64 Cay Dollerup, Teaching Translation and Interpreting 2, Insights, Aims, Vissions (Amsterdam: John Benjamin Publishing Company, 1994), 25.

65 Newmark, Approaches to Translation, 79.

66 Soemarno, 'Studi tentang Kesalahan Terjemahan Bahasa Inggris ke dalam Bahasa Indonesia oleh Mahasiswa yang Berbahasa Ibu Bahasa Jawa', 30.

67 Tomasouw, Buku Materi Pokok Cross-Culture Understanding, 1.3.
} 
between language and culture, the CCU is really significant in translation, it can be ascertained that good translation needs to be supported by the CCU. Good translators need to be able to act as part of the culture involved in translation, which includes source language culture, target language culture, and may be other cultures.

If it is examined, the significance of the CCU in translation is obvious in the translator's efforts to address at least two things: (1) manifest the equivalence of meaning and message content (2) the emergence of various aspects of culture. By the CCU support, translators are not too difficult to find the precise words, terms or phrases for the message they want to transfer. For example, the word 'malu' (shame) in Indonesian sentences, "Pak Lurah malu mengatakannya kepada Pak Bupati" ("The Head of the Village is ashamed to say it to the Regent"), not necessarily can be stated as 'isin' in Javanese. It could be, the more appropriate phrase for that is 'sungkan' (hesitate, respect) so that if it is translated into Javanese, the sentence becomes, "Pak Lurah sungkan matur marang Pak Bupat?", instead of "Pak Lurah isin matur marang Pak Bupati". In choosing one of the two terms, the translator was guided by his understanding of universal Indonesian culture, and his understanding of typical Javanese culture with the nuances of feudalistic lurah-Bupati relationship. How to translate colors in Hanunoo language in the Philippines into Indonesian? In the
Hanunoo language there are only four kinds of colors, mabiru (dark), malagti? (bright colors), marara? (red group) and malatuy (green, yellow, brown group). ${ }^{68}$ Can mabiru be translated as black, blue or gray? There is even a language in Irian, which merely knows two colors, the language of Team in Nigeria knows three colors, the Teeltal language in Mexico knows five colors, six colors in Tamil, eleven-color English. ${ }^{69}$ For example, the following translations might be paid attention to.

Javanese: Iwak pitik olah-olahe bojone isih panggah mbegegeg ana meja makan ing ngarepe. Pak lurah sangga uwang, mripate tan kendhat nglangut nyawangi Si Bagong, perkutute sing awit mau manggung, kaya-kaya ora gelem ngerteni judhege atine Pak Lurah. Isih keprungu cetho ana ing kupinge, Pak Bupati esuk mau ngalem kutut kuwi,"Wah, apik tenan kututmu, Pak Lurah!"

Indonesian: Lauk ayam hasil olahan isterinya masih tetap berada di atas meja makan di depannya, tida disentuhnya. Pak Lurah bertopang dagu, sambil matanya menerawang, terus memandangi burung perkututnya yang sejak tadi berkicau, seolah tak merasakan kesedihannya. Masih jelas terdengar ucapan Pak Bupati memuji burung itu, "Wah, bagus benar perkututmu, Pak Lurah!"

\footnotetext{
68 Geoffrey Leech, Semantics (Middlesex: Penguin Book Ltd, 1976), 29.

69 Lubis, Analisis Wacana Pragmatik, 118.
} 
The translation can be stated unsuccessful because the translator does not use the cross-cultural understanding, in this case he does not understand the sociocultural conditions of the Javanese community. The reader of this translation will certainly ask by using his logic, why after Mr. Bupati complimented his turtledove, Mr. Lurah, head of the village was sad, until he had no appetite? Logic outside of Javanese culture will question that. Translators should realize that for the Javanese society, there is a 'magical' relationship between turtledove and the owner, and in Javanese culture, it's not possible to say no "... tidak dikenal kata tidak." The Javanese recognize the phrase, "Sing sopo ngerti ing panuju, prasasat pagere wesi" (Whoever understands how to please someone's heart, he can be described as fenced or shielded by iron; that is, his position will be strong). ${ }^{71}$

So in the example above, $M r$. Bupat'si compliment is a sign that he pleases with the turtledove and wants it. Such a sign, in the context of the 'LurahBupati' relationship is even translated as a command. That is what makes the Lurah sad. An American translator, for example, who is accustomed to being straightforward, can be confused reading this snippet, because a praise is a praise, a command is a command." Therefore, it becomes the obligation of the translator to explore social

70 Marbangun Hardjowirogo, Manusia Jawa (Jakarta: Yayasan Sedayu, 1983), 12.

71 Hardjowirogo, 13. background as well, especially for the translation of fictional works where the events occur in the story he is translated," explained Hardjoprawiro. ${ }^{72}$

In relation to cross-cultural understanding (CCU), literary theory also contributes to translation. In the field of literature, translators will face many more complicated problems because they involve subjective aesthetic values. Can a translator free himself from TL beauty standard to enter the SL beauty standard area, if he does not understand literary theory, which originates from both languages? For example, how does he re-express the beauty of 'serat Wedhatama' by KGPAA Mangkuneggara IV in English? Or, how does he translate French poetry into English? Isn't the connotation of a word individual?. ${ }^{73}$ Do not the words in French have more nuances of meaning and connotation than English?. ${ }^{74}$ Without the support of literary theory, translation of literary works is impossible to carry out.

\section{Conclusion}

In applied linguistics, translation is a complex figure, not just a substitution of language in a text, but in the form of a whole process of transferring messages from $S L$ to $T L$, while maintaining style and taking into account the readability of the its results. The translation step cannot be carried out optimally by

\footnotetext{
72 Hardjoprawiro, Bahasa Indonesia Dalam Terjemahan, 5.

73 Hollander, Penerjemahan Suatu Pengantar, 43.

74 Newmark, About Translation, 165.
} 
relying solely on linguistic theory. In addition to linguistic theory and the theory of translation itself, there are several disciplines that need to be involved to support the steps of translation, such as Sociolinguistics, Psycholinguistics, pragmatic discourse analysis, contrastive analysis and crosscultural understanding.

\section{References}

Aitchison, Jean. The Articulate Mammal: An Introduction to Psycholinguistics. London: Routledge, 1993.

Baker, Mona. In Other Words, A Course Book on Translation. London: Routledge, 1992.

Baradja, Farid M. 'A Contrastive Analysis of Selected Patterns of the Noun Phrases and Verb Phrases of English and Indonesian'. Dissertation, University of California, 1971.

Bell, Roger T. Translation and Translating: Theory and Practice. London: Longman, 1997.

Brislin, Richard W. Translation Application and Research. New York: Gardner Press Inc, 1976.

Caron, Jean. An Introduction to Psycholinguistics. New York: Harvester Weatsheat, 1992.

Catford, J. C. A Linguistik Theory of Translation. New York: Oxford University Press, 1974.

\footnotetext{
- A Linguistik Theory of Translation. New York: Oxford University Press, 1974.
}

Crystal, David. A Dictionary of Linguistics and Phonetics. United Kingdom: Basil Blackwell Ltd, 1985.

Dollerup, Cay. Teaching Translation and Interpreting 2, Insights, Aims, Vissions. Amsterdam: John Benjamin Publishing Company, 1994.

Duff, Allan. The Third Language. Oxford: Pergamon Press, 1981.

Frawley, William. Translation, Literary, Linguistic, and Philosophical Perspective. London: Associated University Press, 1984.

Garman, Michael. Psycholinguistics. Cambridge: Cambridge University Press, 1994.

Grice, H. Paul. 'Logic and Conversation'. in in Cole, P. and Morgan, J, Syntax and Semantics. New York: Academic Press, 1975.

Halliday, and Ruqaiya Hasan. Bahasa, Konteks, Dan Teks; AspekAspek Bahasa Dalam Pandangan Semiotik Sosial. Yogyakarta: Gadjah Mada University Press, 1994.

Hardjoprawiro, Kunardi. Bahasa Indonesia Dalam Terjemahan. Surakarta: Universitas Sebelas Maret, 1998.

- Menerjemahkan Novel. Jakarta: Pusat Pembinaan dan Pengembangan Bahasa, 1978.

Hardjowirogo, Marbangun. Manusia Jawa. Jakarta: Yayasan Sedayu, 1983.

Hollander, H. W. Penerjemahan Suatu Pengantar. Jakarta: Erasmus Tallcentrum, 1995. 
Koentjaraningrat.

Pokok-Pokok

Antropologi Budaya. Jakarta:

Gramedia, 1984.

Lado, Robert. Language Teaching. New

York: Mc. Grow Hill, 1964.

Larson, Mildred L. Meaning Based Translation. Maryland: University Press of America, 1984.

Leech, Geoffrey. Semantics. Middlesex: Penguin Book Ltd, 1976.

Lubis, Hamid Hasan. Analisis Wacana Pragmatik. Bandung: Angkasa, 1994.

Mackey, W. F. Language Teaching Analysis. London: Longman, 1965.

Nababan, Rudolf M. Teori Menerjemah Bahasa Inggris. Yogyakarta: Pustaka Pelajar, 1999.

Newmark, Peter. About Translation. Clevedon: Multilingual Matters Ltd, 1991.

- Approaches to Translation. Oxford: Pergamon Press, 1981.

Nida, Eugena A. Language Structure and Translation. Stanford: Stanford University Press, 1975.

- - Toward A Science of Translating. Leiden: E. J. Brill, 1964.

Pateda, Mansoer. Sosiolinguistik. Bandung: Angkasa, 1991.

Poerwadarminta, W. J. S. Kamus Umum Bahasa Indonesia. Jakarta: Balai Pustaka, 1976.

Sadtono, E. Pedoman Penerjemahan. Jakarta: Pusat Pembinaan dan Pengembangan Bahasa, 1985.
Savory, Theodore. The Art of Translation. London: Jonathan Cape Thirty Bedford Square, 1969.

Simatupang, Maurits. Enam Makalah Tentang Terjemahan. Jakarta: UKI Press, 1993.

- Enam Makalah Tentang Terjemahan. Jakarta: UKI Press, 1993.

Soemarno, Thomas. 'Studi Tentang Kesalahan Terjemahan Bahasa Inggris ke Dalam Bahasa Indonesia Oleh Mahasiswa Yang Berbahasa Ibu Bahasa Jawa'. Magister Thesis, IKIP Malang, 1983.

Suryawinata, Zuchridin. 'Analisis Dan Evaluasi Terhadap Terjemahan Novel Sastra The Adventures of Huckleberry Finn Dari Bahasa Inggris Ke Bahasa Indonesia'. Dissertation, FPS IKIP Malang, 1982.

Thomas, Noel, and Richard Towell. Interpreting as a Language Teaching Technique. United Kingdom: University of Salford, 1985.

Tomasouw, Pauline. Buku Materi Pokok Cross-Culture Understanding. Jakarta: Karunia, 1986.

Widyamartaya, A. Seni Menerjemahkan. Yogyakarta: Kanisius, 1989. 